\title{
Bahan ajar persamaan diferensial berbasis higher order thinking skills
}

\author{
Nurul Arfinanti \\ Prodi Pendidikan Matematika, Fakultas Sains dan Teknologi, Universitas islam \\ Negeri Sunan Kalijaga, Jalan Marsda Adisucipto, DIY, \\ nurul.arfinanti@uin-suka.ac.id
}

Received: 23 Februari 2020; Accepted: 20 Mei 2020; Published: 20 Juni 2020

\begin{abstract}
Abstrak
Tujuan dari penelitian ini adalah untuk menghasilkan bahan ajar mata kuliah persamaan diferensial berbasis higher order thinking skills yang berkualitas. Hal ini dilatabelakangi dari pentingnya melatihkan HOTS pada calon guru sehingga mereka dapat melatihkannya pula pada siswa. Penelitian ini merupakan penelitian pengembangan dan menggunakan prosedur penelitian pengembangan yang dikemukan oleh Thiagarajan, yaitu 4D (Define, Design, Development, dan Disseminate). Instrumen pengumpulan data yang digunakan terdiri atas lembar validasi ahli, lembar respon mahasiswa, dan soal tes. Hasil penelitian menunjukkan bahwa bahan ajar mata kuliah Persamaan Diferensial berbasis HOTS telah dikembangkan dengan baik dan memenuhi standar minimal dari kualitas bahan ajar. Penilaian dari tiga orang ahli memperoleh persentase keidealan skor rata-rata $91,66 \%$, berada pada kategori sangat baik sedangkan respon mahasiswa terhadap bahan ajar memperoleh persentase keidealan $75,89 \%$, berada pada kategori sangat baik.
\end{abstract}

Kata kunci: bahan ajar, persamaan diferensial, higher thinking skills

\begin{abstract}
The purpose of this research is to produce teaching materials for differential equations based on higherorder thinking skills. HOTS training for prospective teachers is important so that they can train it also for students. This research is a development study and uses a development research procedure revealed by Thiagarajan, namely $4 D$ (Define, Design, Development, and Disseminate). Data collection instruments used consisted of expert validation sheets, student response sheets, and test questions. The results of the study show that HOTS-based Differential Equation courses have been well developed and meet minimum standards of quality of teaching materials. The assessment of the three experts obtained the percentage of ideals of the average score of $91.66 \%$, which is in the very good category. At the same time, the response of students to teaching materials gained a percentage of ideals $75.89 \%$, which is in the very good category.
\end{abstract}

Keywords: teaching materials, differential equations, higher order thinking skills 



\section{PENDAHULUAN}

Tahun 2018 telah dilaksanakan Ujian Nasional untuk tingkat SMP dan SMA dengan menggunakan soal-soal bertipe higher order thinking skills (HOTS). Hasilnya adalah terjadi penurunan nilai khususnya pada mata pelajaran matematika. Kemampuan berpikir tingkat tinggi sebenarnya dapat dilatihkan kepada siswa. Penurunan terhadap hasil ujian nasional matematika kemungkinan disebabkan karena siswa belum terbiasa dengan soal-soal bertipe HOTS. Beberapa kajian juga sudah mengungkapkan kesulitan siswa dalam menyelesaikan soal-soal bertipe HOTS (Muslim, Ikhsan, \& Abidin, 2018).

Pembelajaran berorientasi HOTS telah mulai diterapkan seiring dengan diberlakukan Kurikulum 2013 (Jailani \& Retnawati, 2016); (Fanani \& Kusmaharti, 2018). Keterampilan berpikir tingkat tinggi sejauh ini sudah sering dicoba untuk dilatihkan pada siswa tetapi masih sedikit yang mencoba melatihkannya pada mahasiswa khususnya mahasiswa calon guru. Mahasiswa perlu dibekali HOTS sehingga mereka dapat melatihkannya pada siswa. Terdapat tiga aspek penting yang harus diperhatikan dalam pembelajaran berorientasi HOTS, yaitu kurikulum, pedagogy, dan assessment (Abdullah, et al., 2017). Kemampuan berpikir tingkat tinggi dapat dilatihkan melalui integrasi dengan materi perkuliahan. Bahan ajar perkuliahan dapat didesain untuk memfasilitasi keterampilan berpikir tingkat tinggi dari mahasiswa.

Bahan ajar adalah bahan-bahan atau materi pelajaran yang disusun secara sistematis yang digunakan guru dan siswa dalam proses pembelajaran (Sadjati, 2012, p. 1.20). Bahan ajar merupakan sarana untuk menyampaikan pesan pembelajaran kepada siswa atau mahasiswa sebagai penerima pesan. Pendidik dapat menyampaikan pesan pembelajaran maupun pesan moral ke dalam bahan ajar mereka sehingga pesan tersebut dapat sampai kepada penerima pesan. Pesan agar siswa atau mahasiswa dapat memiliki keterampilan berpikir kritis dapat dimunculkan dalam suatu bahan ajar.

Penelitian yang berupaya mengembangkan bahan ajar sudah banyak dikaji, seperti penelitian yang dilakukan oleh Winarno, dkk (Winarno, Sunarno, \& Sarwanto, 2015). Dalam penelitian tersebut dikatakan bahwa ketersediaan bahan ajar yang sesuai dengan kurikulum masih kurang. Selain itu pada bagian saran juga disebutkan untuk melatihkan keterampilan berpikir tingkat tinggi pada siswa atau mahasiswa. Hal ini membuat peneliti termotivasi untuk mengembangkan bahan ajar untuk mahasiswa agar mereka memiliki kemampuan berpikir tingkat tinggi yang nantinya harus mereka latihkan pada siswa. Meriyanto, dkk juga melakukan pengembangan pengembangan bahan ajar berbasis scientific method untuk meningkatkan kemampuan berpikir tingkat tinggi dan mengembangkan sikap sosial pada materi kemagnetan dan pemanfaatannya (Meriyanto, Sudomo, \& Maryanto, 2017, pp. 1-7).

Siswa yang terlibat dengan HOTS memiliki ciri-ciri: memvisualisasikan masalah dalam bentuk gambar atau diagram, memisahkan informasi yang berguna dan tidak berguna untuk menyelesaikan masalah, mencari alasan dan penyebab, memeriksa kebenaran dari suatu solusi, melihat permasalahan dari berbagai sisi berdasarkan sumber informasi yang kredibel, mengungkapkan asumsi dalam memberikan alasan, dan mengidentifikasi bias atau logika berpikir yang tidak konsisten (Mainali, 2012).

Mata kuliah persamaan diferensial merupakan salah satu mata kuliah wajib yang diajarkan pada program studi pendidikan matematika UIN Sunan Kalijaga (Penyusun, 2013). Mata kuliah ini membahas tentang berbagai macam metode dalam menyelesaikan persamaan diferensial biasa (Murtiyasa \& Khotimah, 2013). Mahasiswa dapat melatih keterampilan berpikir tingkat tingginya dengan menyelesaikan berbagai macam persoalan tentang pencarian solusi dari persamaan 
Bahan ajar persamaan diferensial berbasis higher order thinking skills

diferensial biasa. Meskipun demikian, bahan ajar yang selama ini digunakan masih belum dirancang dalam rangka pengembangan keterampilan berpikir tingkat tinggi mahasiswa. Bahan ajar yang digunakan adalah berbagai buku tentang persamaan diferensial yang tidak dirancang secara khusus untuk meningkatkan keterampilan berpikir tingkat tinggi mahasiswa.

Berdasarkan latar belakang di atas maka peneliti melakukan penelitian pengembangan bahan ajar mata kuliah persamaan diferensial berbasis HOTS. Bahan ajar mata kuliah persamaan diferensial disusun dengan memperhatikan aspek-aspek dari keterampilan berpikir tingkat tinggi. Tujuan penelitian ini adalah untuk mengembangkan bahan ajar mata kuliah Persamaan Direfensial Berbasis HOTS yang berkualitas.

\section{METODE}

Salah satu metode yang sesuai untuk mengembangangkan bahan ajar mata kuliah persamaan diferensial adalah penelitian dan pengembangan (Research and Development, R\&D). Prosedur penelitian yang digunakan dalam penelitian pengembangan ini merujuk pada prosedur penelitian pengembangan yang dikemukan oleh Thiagarajan (Sugiyono, 2016). Langkah-langkah penelitian dan pengembangan tersebut disingkat dengan $4 \mathrm{D}$, yang merupakan perpanjangan dari Define, Design, Development, dan Disseminate. Dalam penelitian ini langkah-langkah tersebut dimodifikasi menjadi tiga langkah (3D model), yaitu define, design, dan develop.

Instrumen pengumpulan data yang digunakan dalam penelitian ini adalah lembar validasi untuk ahli, angket respon mahasiswa, dan soal tes. Ujicoba dilakukan pada mahasiswa Program Studi Pendidikan Matematika UIN Sunan Kalijaga Yogyakarta yang mengambil mata kuliah Persamaan Diferensial Semester Gasal Tahun Akademik 2019/2020.
Instrument pengumpulan data disusun berdasarkan aspek-aspek yang telah ditetapkan dalam pembuatan bahan ajar yang baik serta aspek-aspek HOTS. Bahan ajar dikatakan layak jika memenuhi kriteria kualitas yang telah ditetapkan, yaitu dinilai baik atau sangat baik oleh validator dan mahasiswa.

\section{HASIL DAN PEMBAHASAN}

Hasil pada Tahap Define (Pendefinisian) Pada tahap ini juga dihasilkan beberapa hasil identifikasi terkait dengan kompetensi dasar, karakteristik mahasiswa, kemampuan awal mahasiswa, serta tujuan pembelajaran dan indikator pencapaian hasil belajar. Berikut adalah hasil identifikasi tersebut.

a. Hasil identifikasi kompetensi diperoleh bahwa setiap sub materi yang ajarkan pada mata kuliah Persamaan Diferensial dapat didesain untuk melatihkan HOTS pada mahasiswa. Meskipun demikian yang dikembangkan dalam penelitian ini merupakan materi awal pada mata kuliah Persamaan Diferensial.

b. Hasil identifikasi karakteristik mahasiswa diperoleh bahwa karakteristik sebagian besar mahasiswa program studi pendidikan matematika UIN Sunan Kalijaga mempunyai tipe belajar visual. Dengan karakeristik tersebut, maka bahan ajar yang sesuai adalah bahan ajar yang dapat mendukung visualisasi mahasiswa, yaitu bahan ajar berbentuk cetak. Bahan ajar berbentuk cetak dapat digunakan untuk menuliskan hasil berpikir mahasiswa.

c. Hasil identifikasi kemampuan awal mahasiswa menunjukkan bahwa mahasiswa memiliki kemampuan awal yang beragam. Sebagian besar dari mahasiswa berada pada level sedang. Berdasarkan hal tersebut perlu disusun bahan ajar yang dapat memfasilitasi mahasiswa mulai dari kemampuan rendah, sedang, maupun tinggi.

d. Hasil identifikasi terhadap tujuan pembelajaran dan indikator pencapaian hasil belajar menunjukkan bahwa tujuan 
pembelajaran pada mata kuliah persamaan diferensial.

Hasil pada Tahap Design (Perancangan)

Tahap perancangan dilakukan dalam beberapa langkah, yaitu:

a. Langkah pertama, menyusun kebutuhan dalam pembuatan bahan ajar sesuai dengan capaian pembelajaran (learning outcomes) mata kuliah Persamaan diferensial dalam Kurikulum Kerangka Kualifikasi Nasional Indonesia). Pada langkah ini, peneliti mencermati kemampuan kerja yang diharapkan dapat dicapai oleh mahasiswa pada mata kuliah Persamaan diferensial. Peneliti juga mencermati RPS (Rencana Pembelajaran Semester) pada mata kuliah Persamaan diferensial.

b. Langkah kedua, menyusun butir-butir materi yang disajikan dalam bahan ajar sesuai dengan capaian pembelajaran yang diharapkan.

\section{Hasil pada Tahap Develop (Pengembangan)}

Pada tahap ini dilakukan validasi, revisi, dan ujicoba lapangan terbatas untuk menghasilkan produk akhir (bahan ajar mata kuliah Persamaan diferensial yang berkualitas). Bahan ajar yang dikembangkan dikatakan berkualitas jika memperoleh penilaian minimal baik dari semua validator dan memperoleh respon yang baik atau sangat baik dari mahasiswa. Berikut adalah rincian hasil pada tahap pengembangan (develop).

\section{a. Hasil Validasi dari Ahli}

Ahli yang melakukan validasi bahan ajar memiliki kompetensi untuk menilai materi persamaan diferensial yang ditunjukkan dengan pendidikan minimal Strata 2 dalam bidang matematika. Ahli yang menilai bahan ajar dalam penelitian ini terdiri atas tiga orang yang memenuhi standar kualifikasi yang telah ditetapkan. Pada Tabel 1 disajikan penghitungan hasil penilaian kualitas bahan ajar menurut ahli.

Tabel 1.Hasil Validasi Ahli

\begin{tabular}{|c|c|c|c|c|c|}
\hline Aspek & 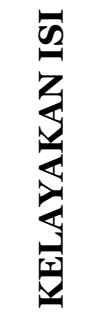 & $\sum_{\substack{\mathbf{3} \\
\mathbf{Z}}}^{\mathrm{Z}}$ & 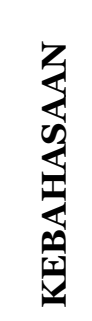 & 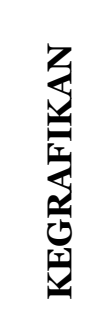 & 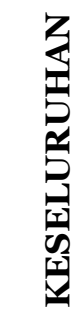 \\
\hline $\begin{array}{l}\sum \text { butir } \\
\text { kriteria }\end{array}$ & 9 & 4 & 4 & 3 & 20 \\
\hline skor tertinggi & 4 & 4 & 4 & 4 & 4 \\
\hline $\begin{array}{l}\text { skor } \\
\text { terendah }\end{array}$ & 1 & 1 & 1 & 1 & 1 \\
\hline $\begin{array}{l}\text { skor tertinggi } \\
\text { ideal }\end{array}$ & 36 & 16 & 16 & 12 & 80 \\
\hline $\begin{array}{l}\text { skor } \\
\text { terendah } \\
\text { ideal }\end{array}$ & 9 & 4 & 4 & 3 & 20 \\
\hline $\begin{array}{l}\bar{x} \text { (skor rata- } \\
\text { rata) }\end{array}$ & 33,7 & 15 & 14,3 & 10,3 & 73,3 \\
\hline $\begin{array}{l}S B_{i} \\
\text { (Simpangan } \\
\text { baku ideal) }\end{array}$ & 4,5 & 2 & 2 & 1,5 & 10 \\
\hline $\begin{array}{l}M_{i} \text { (rata-rata } \\
\text { ideal) }\end{array}$ & 22,5 & 10 & 10 & 7,5 & 50 \\
\hline $\begin{array}{l}\text { Persentase } \\
\text { Keidealan }\end{array}$ & 93,5 & 93,7 & 89,5 & 86,1 & 91,6 \\
\hline Kategori & SB & SB & SB & SB & SB \\
\hline
\end{tabular}

Secara umum persentase keidealan dari tiaptiap aspek akan disajikan pada Gambar 1 berikut.

\section{Persentase Keidealan Kualitas Bahan Ajar Menurut Ahli}

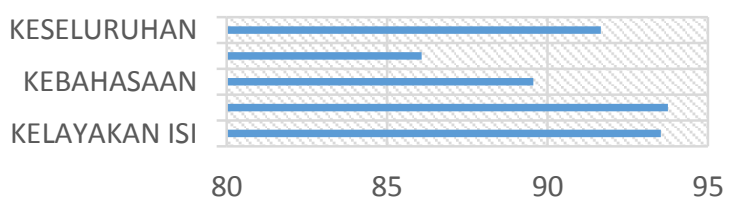

Gambar 1. Persentase Keidealan Kualitas Bahan Ajar Menurut Ahli

Jurnal Analisa 6 (1) (2020):10-18 
Berikut adalah beberapa masukan dari ahli terhadap bahan ajar mata kuliah Persamaan Diferensial berbasis HOTS.

Tabel 2.Masukan dari Validator

\begin{tabular}{|c|c|}
\hline Ahli & Masukan untuk Bahan Ajar \\
\hline \multirow[t]{7}{*}{ Ahli 1} & Tujuan pada bab 2.1 kurang jelas \\
\hline & Ada beberapa kalimat yang ambigu \\
\hline & Gambar kurang besar ukurannya \\
\hline & $\begin{array}{l}\text { Tujuan cukup jelas, tetapi ada } \\
\text { beberapa kalimat dalam tujuan yang } \\
\text { bermakna ganda }\end{array}$ \\
\hline & $\begin{array}{l}\text { Kalimat yang digunakan interaktif } \\
\text { dan komunikatif, sehingga terkesan } \\
\text { memakai bahasa nonformal (belum } \\
\text { sesuai EYD) }\end{array}$ \\
\hline & $\begin{array}{l}\text { Penyajian materi bagus, dapat } \\
\text { mengajak pembaca untuk berpikir } \\
\text { kritis dan berpikir kreatif }\end{array}$ \\
\hline & $\begin{array}{l}\text { Ada beberapa subbab (bagian) yang } \\
\text { pada akhir materi tidak memberikan } \\
\text { latihan soal/diskusi. Sebaiknya pada } \\
\text { setiap bagian (subbab) diberikan } \\
\text { latihan soal/diskusi yang dapat } \\
\text { sesuai dengan indikator soal HOTS }\end{array}$ \\
\hline \multirow[t]{3}{*}{ Ahli 2} & $\begin{array}{lr}\text { Ditambahkan } & \text { permasalahan yang } \\
\text { menghasilkan } & \text { gagasan-gagasan } \\
\text { berbeda-beda } & \\
\end{array}$ \\
\hline & Semua gambar sebaiknya berwarna \\
\hline & $\begin{array}{l}\text { Bahan ajar mata kuliah persamaan } \\
\text { diferensial berbasis HOTS ini sudah } \\
\text { sangat baik, sebagai tambahan agar } \\
\text { semua gambar atau ilustrasi } \\
\text { disajikan berwarna agar lebih } \\
\text { menarik }\end{array}$ \\
\hline \multirow[t]{2}{*}{ Ahli 3} & $\begin{array}{l}\text { Ada beberapa kalimat yang tidak } \\
\text { baku, penggunaaan bahasa yang } \\
\text { menarik juga harus memperhatikan } \\
\text { kaidah yang ada. }\end{array}$ \\
\hline & $\begin{array}{l}\text { Permasalahan kontekstual dapat } \\
\text { diberikan pada awal sehingga dapat } \\
\text { membangun keterampilan berpikir } \\
\text { siswa dalam menyelesaikan masalah } \\
\text { tersebut. }\end{array}$ \\
\hline
\end{tabular}

Jurnal Analisa 6 (1) (2020) :10-18
Pada bagian latihan soal sudah cukup baik, hanya saja kurang konsisten. Seharusnya pada setiap bab diberikan soal-soal latihan yang dapat melatih keterampilan berpikir tingkat tinggi mahasiswa, yaitu salah satunya dengan memberikan soalsoal cerita yang sesuai dengan konteks mahasiswa

Gambar tentang penggunaan persamaan diferensial sehari-hari perlu ditambahkan agar memberikan gambaran kepada mahasiswa tentang pentingnya mempelajari persamaan diferensial sehingga dapat menumbuhkan miotivasi dalam belajar persamaan diferensial

Sebaiknnya dibuat peta konsep mata kuliah persamaan diferensial pada bagian awal buku, sehingga memudahkan pembaca melihat hubungan antara bab satu dengan bab lainnya

Kesimpulan yang dapat dibuat berdasarkan hasil validasi dari ahli terhadap bahan ajar mata kuliah Persamaan diferensial berbasis higher order thinking skills adalah bahan ajar tersebut dapat diujicobakan kepada mahasiswa dengan perbaikan seperlunya. Hal ini dikarenakan bahan ajar tersebut memperoleh penilaian pada kategori sangat baik oleh ketiga validator ahli.

b. Hasil Respon Mahasiswa terhadap Bahan ajar Mata kuliah Persamaan diferensial

Setelah melalui tahap validasi oleh ahli, kemudian dilakukan ujicoba terbatas untuk mendapatkan respon dari mahasiswa. Mahasiswa diminta untuk mengisi lembar angket respon mahasiswa terhadap bahan ajar mata kuliah Persamaan diferensial berbasis HOTS. Lembar angket diberikan setelah mahasiswa mengalami pembelajaran mata kuliah Persamaan Diferensial menggunakan bahan ajar yang dikembangkan.

Tabel 3 merupakan rangkuman hasil respon mahasiswa terhadap penggunaan bahan ajar 
mata kuliah Persamaan Diferensial berbasis

HOTS.

Tabel 3. Hasil Respon Mahasiswa Terhadap Bahan ajar Mata kuliah Persamaan Diferensial Berbasis HOTS

\begin{tabular}{|c|c|c|c|c|c|}
\hline \multirow{2}{*}{ No } & \multirow{2}{*}{ Penilai } & \multicolumn{3}{|c|}{ Hasil Penilaian Tiap Aspek } & \multirow{2}{*}{ Keseluruhan } \\
\hline & & Kelayakan Isi & Kebahasaan & Kegrafikan & \\
\hline 1 & Mahasiswa 1 & 28 & 8 & 12 & 6 \\
\hline 2 & Mahasiswa 2 & 29 & 9 & 12 & 6 \\
\hline 3 & Mahasiswa 3 & 27 & 10 & 12 & 7 \\
\hline 4 & Mahasiswa 4 & 28 & 10 & 11 & 6 \\
\hline 5 & Mahasiswa 5 & 31 & 10 & 12 & 6 \\
\hline 6 & Mahasiswa 6 & 27 & 10 & 11 & 6 \\
\hline 7 & Mahasiswa 7 & 27 & 10 & 12 & 5 \\
\hline 8 & Mahasiswa 8 & 30 & 9 & 12 & 6 \\
\hline 9 & Mahasiswa 9 & 29 & 9 & 12 & 5 \\
\hline 10 & Mahasiswa 10 & 31 & 9 & 15 & 7 \\
\hline 11 & Mahasiswa 11 & 27 & 8 & 14 & 5 \\
\hline 12 & Mahasiswa 12 & 29 & 10 & 14 & 6 \\
\hline 13 & Mahasiswa 13 & 31 & 9 & 11 & 6 \\
\hline 14 & Mahasiswa 14 & 30 & 10 & 14 & 6 \\
\hline 15 & Mahasiswa 15 & 29 & 11 & 14 & 7 \\
\hline 16 & Mahasiswa 16 & 28 & 10 & 16 & 6 \\
\hline 17 & Mahasiswa 17 & 25 & 10 & 10 & 6 \\
\hline 18 & Mahasiswa 18 & 35 & 10 & 12 & 6 \\
\hline 19 & Mahasiswa 19 & 28 & 12 & 13 & 5 \\
\hline 20 & Mahasiswa 20 & 30 & 10 & 11 & 5 \\
\hline 21 & Mahasiswa 21 & 35 & 11 & 16 & 8 \\
\hline 22 & Mahasiswa 22 & 31 & 10 & 13 & 5 \\
\hline 23 & Mahasiswa 23 & 31 & 9 & 11 & 7 \\
\hline 24 & Mahasiswa 24 & 30 & 7 & 11 & 6 \\
\hline 25 & Mahasiswa 25 & 27 & 9 & 12 & 6 \\
\hline 26 & Mahasiswa 26 & 34 & 12 & 16 & 7 \\
\hline 27 & Mahasiswa 27 & 35 & 12 & 16 & 8 \\
\hline 28 & Mahasiswa 28 & 26 & 10 & 11 & 5 \\
\hline & Jumlah & 828 & 274 & 356 & 170 \\
\hline & Rata-rata & 29,57 & 9,79 & 12,71 & 6,07 \\
\hline $\mathrm{Sk}$ & Maksimal Ideal & 36 & 12 & 16 & 8 \\
\hline Per & entase Keidealan & $82,14 \%$ & $81,55 \%$ & $79,46 \%$ & $75,89 \%$ \\
\hline & Kategori & Sangat Baik & Sangat Baik & Sangat Baik & Sangat Baik \\
\hline
\end{tabular}


Berdasarkan Tabel 3 di atas dapat disimpulkan bahwa hasil respon mahasiswa untuk setiap aspek penilaian baik itu kelayakan isi, kebahasaan, dan kegrafikan memperoleh respon sangat baik dari mahasiswa. Hasil ini menunjukkan bahwa bahan ajar mata kuliah Persamaan Diferensial berbasis HOTS telahmemenuhi kriteria kualitas bahan ajar yang telah ditentukan.

\section{Pembahasan}

Penelitian ini bertujuan untuk mengembangkan bahan ajar mata kuliah Persamaan Diferensial berbasis HOTS yang berkualitas. Pada proses ujicoba bahan ajar, peneliti menemukan fakta bahwa mahasiswa sangat menikmati membaca dan menuangkan pemikiran mereka pada bahan ajar yang dibagikan.

Pada bagian awal bab dari bahan ajar mata kuliah persamaan diferensial diberikan motivasi perlunya kita mempelajari mata kuliah persamaan diferensial. Motivasi dapat memberikan pengaruh yang positif terhadap hasil belajar (Jatmiko, 2015). Pada Gambar 2 diperlihatkan bagaimana motivasi diberikan pada bahan ajar mata kuliah persamaan diferensial yang dikembangkan.

\subsection{Motivasi: \\ Di dalam kehidupan ini terdapat banyak sekali pertanyaan-pertanyaan yang cukup menggeltik untuk membuat semua banyak orang, menjadi penasaran akan jawabannya. Salah satu dari pertanyaan-pertanyaan tersebut barang kali adalah adakah keterkaitan di antara fenomena-fenomena yang ada di dunia ini, adakah hukum sebab akibat ber- laku disana?. Di dalam Al-Quran dapat diketemukan ayat-ayat Allah yang berkaitan dengan hukum sebab akibat, antara lain, \\ 1. "Dan masing masing orang memperoleh derajat-derajat (seimbang) dengan apa yang dikerjakannya. Dan Tuhan mu tidak lengah dari apa yang mereka kerjakan" (Al Anam , $6: 132$ ) \\ 2. "Dan apa apa yang menimpa kamu dari musibah, maka disebabkan usaha tangan-mu ; dan DIA memaafkan banyak ( kesalahan-kesalahan kamu )"( Asy Syuuraa, $42: 30$ )}

\section{Gambar 1. Bagian Bahan Ajar Persamaan Diferensial yang Berupa Motivasi}

Konsep hukum sebab akibat tentu saja tetap dalam kontrol Allah tidak berdiri sendiri,

Dan pada sisi Allah-lah kunci-kunci semua yang gaib; tidak ada yang mengetahuinya kecuali Dia sendiri, dan Dia mengetahui apa yang di daratan dan di lautan, dan tiada sehelai daun pun yang gugur melainkan Dia mengetahuinya (pula), dan tidak jatuh sebutir biji-pun dalam kegelapan bumi, dan tidak sesuatu yang basah atau yang kering, melainkan tertulis dalam kitab yang nyata (Lauh Mahfuzh). (al-Anam: 59)

Hukum Allah ini tentunya belaku kepada semua mahkluknya. Dari hukum sebab akibat ini maka dapat diartikan bahwa segala sesuatu yang berada di dunia ini memiliki keterkaiatan dalam pola yang sederhana maupun kompleks. Sebagai contoh sederhana adalah pada kuliah Kalkulus kita ketahui bahwa turunan dari suatu fungsi mengukur bagaimana fungsi berubah. Pada pembahsan selajutnya akan disampaikan lebih mendalam mengenai konsep persamaan-persmaan yang menghubungkan suatu fungsi dengan satu atau lebih turunannya . Hal ini menarik untuk dipelajari karena banyak fenomena-fenomena alam yang terjadi dapat di jelaskan secara matematis dengan melibatkan perubahan-perubahan entitas menggunakan persamaan yang berbeda-beda.

\section{Gambar 2. Bagian Bahan Ajar Persamaan Diferensial yang Berupa Motivasi}

Selain pemberian motivasi tentang pentingnya kita memikirkan fenomena-fenomena alam dan mengkaitkannya dengan mata kuliah persamaan diferensial, mahasiwa juga diberikan contoh-contoh kasus yang dapat dibayangkan oleh mahasiswa. Gambar 3 memperlihatkan contoh kasus yang bersesuaian.

\section{Contoh 1.3.3. (Pertumbuhan Bakteri) Diketahui terdapat 100 bakteri pada saat $t=0$ dan menjadi 200 bakteri setelah 10 detik. Tentukan berapa banyaknya bakteri pada menit pertama?}

\section{Gambar 3. Contoh yang Disajikan pada Bahan Ajar}

Pada bagian akhir bab penulis memberikan bagian "Diskusi" agar mahasiwa dapat memecahkan persoalan yang berkaitan dengan materi yang dipelajari. Gambar 4 menunjukkan contoh materi yang didiskusikan oleh mahasiswa pada bahan ajar. Diskusi penting dilakukan dalam pengembangan kemampuan berpikir kreatif dan pemecahan masalah matematis mahasiswa (Moma, 2017). 


\subsection{Diskusi}

1. Diketahui,pada suatu populasi tikus, tanpa adanya predator tikus berkembang biak, dengan tikat pertumbuhanya sebanding dengan jumlah populasinya. Miskan tumbuhanya tingkat pertumbuhan tikus 0.5 tikus/bulan. Kemudian saat kawanan burung hantu datang, rata-rata burung hantu memakan 15 tikus per hari. Buatlah persamaan diferensial serta lapangan berarah yang menggambarkan kejadian tersebut.

2. Sebuah pegas diletakan pada sembuah meja dengan ujung kiri pegas ditanjakan pada tembok dan ujung kanan pegas di lekatkan sebuah benda dengan massa $m k g$. Jika gaya gesek diabaikan dan benda ditarik/didorong sejauh $x \mathrm{~cm}$ dari keadan normal kemudian di lepaskan buatlah persamaan diferensial yang menggambarakan perubahan gerak pegas tersebut.

\section{Gambar 4. Bagian "Diskusi" Bahan Ajar Persamaan Diferensial Berbasis HOTS}

Dalam kegiatan ujicoba produk mahasiswa diminta untuk mempelajari bahan ajar mata kuliah persamaan diferensial berbasis HOTS. Mereka diminta untuk menguraikan dan memberikan alasan pada setiap langkah penyelesaian yang ada pada bahan ajar. Mahasiswa juga diminta untuk mengevaluasi apakah suatu langkah pengerjaan sudah betul atau belum. Gambar 5merupakan dokumentasi dari hasil pekerjaan mahasiswa.

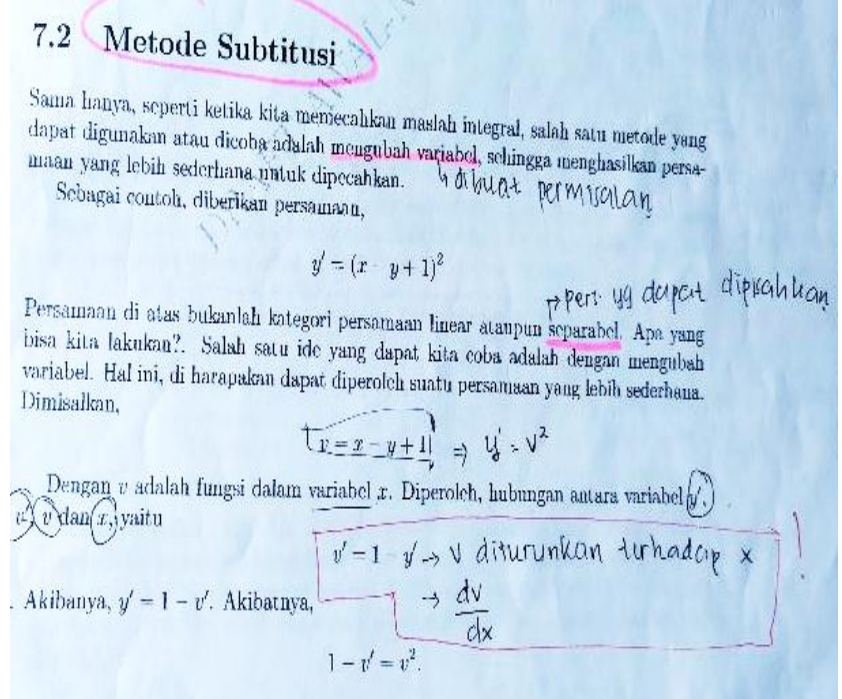

Gambar 5. Hasil Analisis Mahasiswa
Gambar 5 di atas memperlihatkan hasil analisis mahasiswa terhadap materi pada mata kuliah persamaan diferensial. Dari Gambar 5 dapat dilihat bahwa mahasiwa mampu menguraikan suatu rumus matematika dan memberikan penjelasan tambahan mengapa dapat diperoleh formula matematika tersebut.

\section{UCAPAN TERIMAKASIH}

Penulis mengucapkan terimakasih kepada LPPM UIN Sunan Kalijaga yang telah membiayai kegitan penelitian ini melalui skema dana penelitian dasar pengembangan program studi tahun 2019. Penulis juga mengucakna termakasih kepada semua pihak yang telah membantu dalam pembuatan bahan ajar mata kuliah persamaan diferensial berbasis higher order thinking skill.

\section{KESIMPULAN}

Bahan ajar mata kuliah Persamaan Diferensial berbasis HOTS telah dikembangkan dengan baik dan memenuhi standar minimal dari kualitas bahan ajar. Berikut adalah rekap kuliatas dari produk bahan ajar mata kuliah Persamaan Diferensial yang telah dikembangkan. Penilaian dari tiga orang ahli yang mencakup aspek kelayakan isi, penyajian, kebahasaan, kegrafikan memperoleh persentase keidealan skor rata-rata 91,66, berada pada kategori sangat baik. Respon mahasiswa terhadap bahan ajar yang mencakup aspek kelayakan isi, kebahasaan, dan kegrafikan memperoleh persentase keidealan $75,89 \%$, berada pada kategori sangat baik.

\section{Referensi}

Abdullah, A. H., Mokhtar, M., Halim, N. D., Ali, D. F., Tahir, L. M., \& Kohar, U. H. (2017). Mathematics Teachers' Level of Knowledge and Practice on the Implementation of Higher-Order Thinking Skills (HOTS) . EURASIA 
Journal of Mathematics Science and Technology Education , 13(1), 3-17. doi:10.12973/eurasia.2017.00601a

Fanani, A., \& Kusmaharti, D. (2018). Pengembangan Pembelajaran Berbasis HOTS (Higher Order Thinking Skill) di Sekolah Dasar Kelas V. JPD: Jurnal Pendidikan Dasar, 9(1), 1-11. doi:doi.org/10.21009/JPD.091.01

Jailani, \& Retnawati, H. (2016, Oktober). Keefektifan Pemanfaatan Perangkat Pembelajaran Berbasis Masalah untuk Meningkatkan HOTS dan Karakter Siswa. Jurnal Pendidikan Dan Pembelajaran, 23(2), 111-123.

Jatmiko. (2015). Hubungan Motivasi Belajar dengan Hasil Belajar Matematika Siswa Kelas X SMK Nahdhatul Ulama Pace Nganjuk. Jurnal Math Educator Nusantara, 1(2), 205-213.

Mainali, B. P. (2012). Higher Order Thinking In Education. Academic Voices (A Multidisciplinsry Journal), 2(1).

Meriyanto, Sudomo, J., \& Maryanto, A. (2017). Pengembangan Bahan Ajar Berbasis Scientific Method Untuk Meningkatkan Kemampuan Berpikir Tingkat Tinggi Dan Mengembangkan Sikap Sosial Pada Materi Kemagnetan Dan Pemanfaatannya. Jurnal Pendidikan Matematika dan Sains, 6(2), 1-7.

Moma, L. (2017, Februari). Developing Mathematical Creative Thinking and Problem SolvingAbility Through Discussion Method. Jurnal Cakrawala Pendidikan, 36(1), 130-139.

Murtiyasa, B., \& Khotimah, R. P. (2013). Persamaan Differensial Elementer. Surakarta: Muhammadiyah University Press.

Muslim, Ikhsan, M., \& Abidin, T. F. ( 2018). Student Difficulties in Solving High Order Thinking Skills (HOTS) Problem on Geometry Problems Viewed from the Cognitive Styles. Proceedings of The 8th Annual International Conference (AIC) on
Social Sciences, Syiah Kuala University 2018 September 12-14. Banda Aceh.

Penyusun, T. (2013). Buku Panduan Akademik Program Studi Pendidikan Matematika. Yogyakarta: UIN Sunan Kalijaga.

Sadjati, I. M. (2012). Hakikat Bahan Ajar. Universitas Terbuka.

Sugiyono. (2016). Metode Penelitian dan Pengembangan. Bandung: Alfabeta.

Winarno, Sunarno, W., \& Sarwanto. (2015). Pengembangan Modul IPA Terpadu Berbasis High Order Thinking Skill (HOTS) pada Tema Energi. Jurnal Inkuiri, 4(1), 82-91. 